\title{
Current problems with the prerequisites for flipped classroom teaching---a case study in a university in Northwest China
}

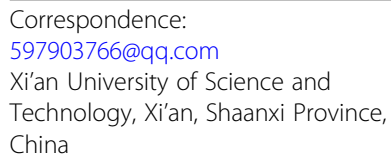

\begin{abstract}
With the rapid advancement of IT, more and more attempts have been made to incorporate this modern technology into education. Of the newest teaching and learning devices and approaches, the use of microlectures and the idea of flipped classroom model(known as FCM) have caught the attention of many teachers. While the new teaching device and the innovative teaching approach succeed in some teachers' classes, they are doomed to failure in others' for this new approach involves prerequisites of which many teachers might not be fully aware of before their teaching practice, the lack of which might become barriers. This paper presents a post hoc analysis of a failed case with FCM and attempts to discuss, at a macroscopic level, problems with preconditions for FCM that currently exist, in the hope that teachers who are making an attempt at FCM can be aware of these problems and thus would make better preparation for it so as not to repeat the failure should they conduct FCM in their teaching. As are revealed by a detailed analysis of the reasons and a further deliberation on the failure with regard to a successful case, students' inadaptability to unmonitored e-learning, teachers' inadequate knowledge of computer science and information technology, the lack of a desirable communication platform and restrictive syllabuses may all hinder the smooth application of FCM, among which, the lack of a desirable communication platform and teachers' lack of adequate knowledge of computer science and information technology have become a bottleneck in the application of FCM.
\end{abstract}

Keywords: FCM, Microlectures, Inadaptability, Communication platform

\section{Background}

A survey of the incorporation of IT into education in any academic database will reveal a vast host of papers covering nearly all fields of study. However, this is only a recent trend in China. While the use of CAI (Computer Aided Instruction) to economize both time and cost was discussed and explored in America in 1990 (Fletcher et al. 1990), computers were rare luxuries to Chinese people. Near the end of the twentieth century there were computers of various descriptions in nearly all American schools and American students used multimedia and the internet to learn interactively, whereas in China, computers were still a luxury to most schools and families and internet was just at an initial developmental stage. China then had a population of over 1.24 billion, but nationwide, only 1.46 million computers were connected to the internet (Sun 1999). It was not until 2006 that

(c) The Author(s). 2018 Open Access This article is distributed under the terms of the Creative Commons Attribution 4.0 International License (http://creativecommons.org/licenses/by/4.0/), which permits unrestricted use, distribution, and reproduction in any medium, provided you give appropriate credit to the original author(s) and the source, provide a link to the Creative Commons license, and indicate if changes were made. 
"to accelerate the process of 'informationized' education and research" was first clearly requested by General Office of the CPC Central Committee (2006), when the traditional image of a teacher with a book in one hand and a piece of chalk in the other was still ubiquitous. Soon the popularity of PC and the advance of internet brought a phenomenal change to education: E-teaching started to reform education and urge teachers to change with the times.

China's 'informationized' teaching started late, but upon the request of the government, and with great efforts invested, it has been trying to catch up with the latest trend of teaching technology and innovative teaching approaches worldwide over quite a short period of time. Over the past few years, following the introduction of PowerPoint style presentations into traditional classroom teaching, microlectures and the revolutionary flipped classroom model (FCM) have continued to stun, excite and motivate teachers. Some consider them a means to cater to every student's need because of the availability of repeated playing of the teaching content and the possibility of free interaction between students and teachers with the aid of modern communication platforms (Yin and Wu 2016). Some take them as a solution to the shortage of class time by allotting students teaching contents to study themselves in their spare time (Rui et al. 2017). Others see an opportunity in them to improve teaching quality and cultivate students' innovativeness, teamwork, manipulative ability, etc., due to more interaction between students and between teachers and students (Chiang and Chen 2017). FCM and microlectures are being viewed as a way out by teachers who are either eager to solve their teaching problems or to improve their teaching quality.

\section{The fundamental premise of FCM}

Based on the existing research into FCM by Baker (2000), Novembe and Mull (2012), Milman (2012), etc., common understanding can be found that teachers' ability to make microlectures and knowledge of information technology, students' knowledge of information technology and a common communication platform between teachers and students are prerequisites for the application of FCM. These seemingly can be met easily: Teachers can learn to make microlectures through training programs which can be found on some educational platforms. (e.g. Higher Education Institutions Teacher Online Training Center, a fully established state-run online training and learning platform popular among college teachers in China since 2012); most college students have learned to use smart phones before going to college and many of them excel at using computers; communication platforms can be apps stored in smart phones like Wechat or QQ chatroom or more convenient communication platforms provided by universities like e-Moodle (Qin and Zhu 2014; Su 2016). Information collected from online resources indicates that the prerequisites for FCM can be easily met and teachers can flip their classes as long as they put in enough effort in their work. But the failed case presented below reveals that the prerequisites mentioned are not easily met and more need to be learned and prepared about this approach before it is applied.

\section{A failed case of FCM in intensive reading class}

\section{The traditional way of teaching vs the planned teaching with FCM}

Traditionally, an intensive English reading class which integrates all the five language skills of listening, speaking, reading, writing and translation is handled by teachers step 
by step in class. After a discussion of leading questions, teachers teach students new words and phrases from the text to read, and then give students time to read the text, and after that guide them to understand the article, and finally help them finish a great number of exercises concerning the five language skills. Everything is done in class except the last activity which would consume too much class time if carried out in class, so the teacher usually asks students to finish them before class and check their answers in class. But in this way, the teacher always feels short of time to fully address the difficult points. Neither can the students get much oral practice due to insufficient interaction.

Encouraged by pioneering senior teachers in China who are keen on modernization in teaching and think highly of this new approach (He 2014; Tian 2014), the author of this paper attempted to use some FCM strategies in her class. The plan was to spare the class time used for low-order learning involving vocabulary study and text reading activity by giving students a microlecture on vocabulary, a text record, word files of general reading comprehension questions as well as corresponding answers for students to study and check before class. Answers to simple exercises were also given to students for self-check before class on the final stage. For every unit which was arranged to take eight to ten periods, an average student would only need to spend one hour on all the assigned work. With basic teaching contents accomplished by students, the teacher would be able to make students work in pairs/groups to have an in-depth discussion of the text as they would have been better prepared for the text. This could not only facilitate students' learning due to more active thinking and participation, but could make more students open their mouths to speak English. Questions from students were expected to increase both in quantity and quality as the result of independent study and more thinking and reflection on their work. The expected results were that the teacher would be able to improve teaching quality by making better use of class time and students would not only learn more effectively, but also gain more opportunities to speak English. The change in the arrangement is shown in Fig. 1.

However, despite the teacher's elaborate preparation for both self-learning materials and class activities, after one month of practice, the attempt at reforming the traditional way of teaching by flipping the class had to be terminated due to the lack of cooperation from students. But observation of students' down-loading habits of self-study materials which indirectly reflect their initiative and ability of voluntary study continued for over a year. The failure and the following year-long observation of students' down-loading habits together with reflection on the successful case of TAL (a private education institution which provides after-school tutoring services in China) enabled the teacher to acquire a much deeper understanding about FCM and its application prerequisites.

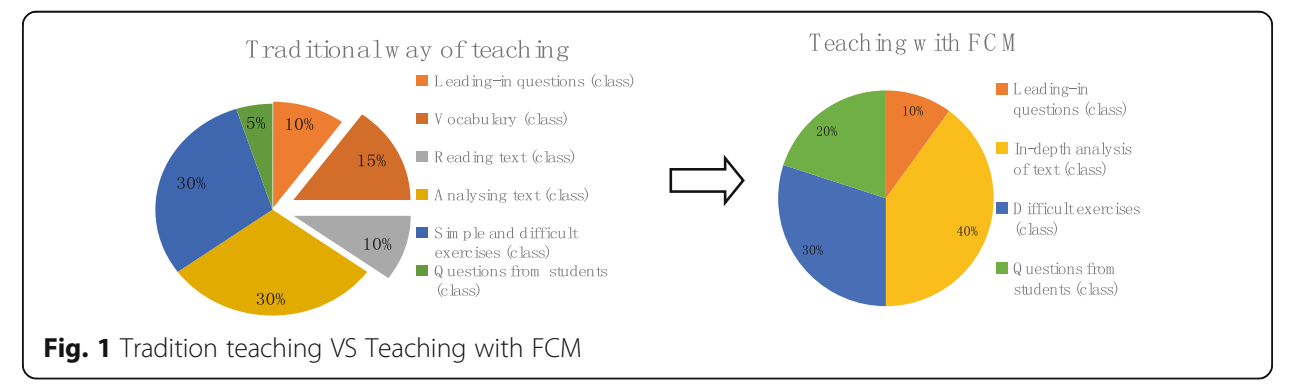




\section{Representativeness of the failed case}

As a teacher at a university ranking 205 on China's 700-University ranking list released by CUAA-Team of China University Evaluation (2017), the author attempted this new teaching approach for the purpose of the accomplishment of more teaching tasks in face of insufficient class time and the improvement of her class teaching quality, the results of which are representative in terms of the overall competitiveness including hardware and software facilities, enrolment quality, academic and social influences as this university is of medium level. And the author, an average teacher in an average university, is typical of many college teachers in terms of experience and knowledge of this approach, capability of computer operation and enthusiasm for e-teaching.

\section{Methodology}

Subjects

Fifty-two first-year English major students in XUST (Xi'an University of Science and Technology, a university in Northwest China) were involved in this teaching intervention and observation without being notified of the approach for approximately one year and a half.

\section{Contexts and methods}

Twenty-six students from Class 1 who were taught the course "Intensive Reading" were taught in this innovative way of teaching for one month, and after that were under observation for their adaptability to self-initiated e-learning for over one year until this course came to an end.

In the first month, before the study of each text, the teacher would give students a video microlecture of new words and phrases for them to learn, accompanied by corresponding exercises for practice and answers to self-check. The audio material of the text in the form of mp3 was also given to students for the purpose of improving their pronunciation and intonation as many students were weak in these aspects. Basic questions about the content of the text were also given to students for reflection and answers to these questions were given separately in MS Word format. In class, the teacher intended to focus on more difficult contents such as difficult sentences and hard-to-understand ideas, cultural backgrounds, writing purposes and writing techniques rather than basic language points as well as basic understanding of the text which in the traditional way of teaching would account for at least two periods of classroom time. Besides the necessary study materials, after each class, the teacher would give students other complementary materials, like the script for a dictation done in class, a movie clip or a song or complementary reading material about interesting cultural phenomena etc. either for the purpose of self-check, or to broaden students' views or simply to entertain them.

One month later when the attempt proved to be a failure and the old way of teaching had to be resumed, the teacher went on uploading useful study materials on line like text records, scripts for dictations done in class, movie clips, songs or complementary reading materials about interesting cultural phenomena.

The other 26 students from Class 2 who were taught "Listening Comprehension" got involved one month later when the approach failed in Class 1 . They were also observed for their adaptability to self e-learning. The purpose was to gather more 
data within the teacher's remit. Besides the normal in-class practice, the teacher assigned them extra home listening materials by uploading them online, together with the necessary answers to questions. The home listening materials included pure listening materials in the form of MP3 (for the purpose of self-training), movie clips and English songs (for the purpose of broadening their views or entertaining them). Word documents with answers to questions and scripts for dictations were also provided for students for self-check.

\section{Facilities}

As freshmen, only five students in total have personal computers, but every student has a smart phone. Without an online teacher-student communication platform provided by the university, as the construction of digital campus is still ongoing in this university as in most universities, the teacher established two QQ groups (QQ is one of China's most popular communication platforms used primarily for personal/leisure use) for Class 1 and Class 2 students respectively.

\section{Results}

Attempts at FCM barely lasted for one month and then were given up. In fact, students in class 1 showed great interest after they were assigned the self-study material for the first text and its downloading rate reached 25. But the following downloading rates were far from satisfactory. Class check of students' work showed that with a few exceptions, most students didn't make necessary preparation for what was designed to be done in class. Students' obvious lack of cooperation made it difficult for the teacher to proceed as planned. After four weeks of attempts, due to students' reluctance to download the teaching materials to study themselves, the old way of teaching had to be resumed and the planned teaching tasks had to be reduced as a result of the shortage of class time.

For the rest of time before the course came to an end, necessary study materials in various forms were uploaded as usual, and observation of students' downloading habits of study materials was continued. The results are shown in Fig. 2.

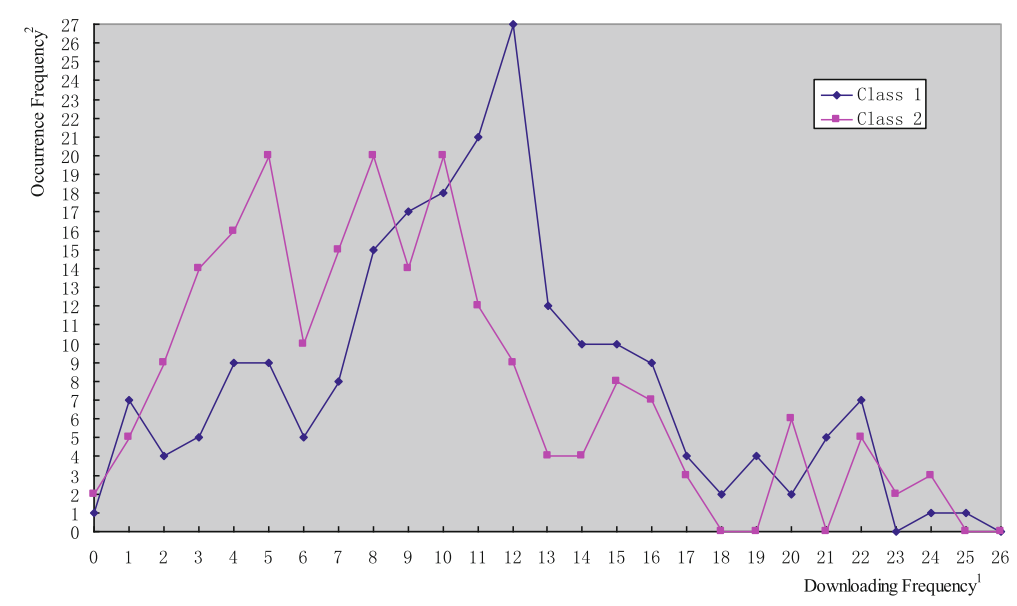

Fig. 2 Downloading frequency VS its occurrence frequency 
Downloading frequency ${ }^{1}$ refers to the number of times for the same material being downloaded. Occurrence frequency ${ }^{2}$ refers to the number of occurrences of the same downloading frequency.

During the one year and a half, Class 1 was provided with 213 online materials and Class 2, 209. From the diagram, we can see not even once did a whole class download a study material. Instead, for Class 1 , once, none of the students downloaded the material and for Class 2, twice. As the number increases on the horizontal axis which shows the downloading rate of a single material increasing from zero to the largest 26 as there are only 26 students in each class, neither graph shows a proportional ascending trend, but rather an irregular one. Both graphs are close to the horizontal axis with large downloading rates and that of Class 2's even touches the horizontal axis at the downloading frequency of 18, 19, 21, 25 and 26, which means these downloading rates never occurred once with Class 2. In comparison, Class 1 shows occurrence frequency of $1,2,4,5,1$ and 0 at the downloading frequency of 18, 19, 21, 25 and 26 respectively, which is very low in general and also the result of teacher's intervention which will be explained in Students' inadaptability to unmonitored e-learning.

For Class 1 , the peak value is 27 , which shows each of 27 different online materials was downloaded 12 times by students from this class, and for Class 2, the peak value is 20, which occurred three times when each of 20 different items was downloaded five times, each of another 20 different items, eight times and each of still another 20 different items, ten times by students from this class (altogether, students from this class downloaded 60 different items at the rates of 5, 8 and 10, with each rate repeated 20 times). For both classes, each with 26 students in it, the peak values occurred when less than half of the students did the downloading work, supposing that each download was done by a different student. As can be seen from the diagram, though the graphs show significant differences between the two classes in details, holistically, both classes showed a striking similarity: the downloading rates were, on the whole, very low, considering the total number of the students in each class.

\section{Analysis}

A follow-up survey was made at the end of the first term (China's school year consists of two terms, each lasting about four to five months). The survey was made to check students' reasons for not downloading the study materials. Of the 52 students, 5 students gave no reasons for they wrote that they had downloaded the materials, for which we can understand that most of the time they downloaded the materials for self-study. Of the other 47 students, the reasons for not downloading (here we understand that most of the time they did not download the materials) are shown as follows.

In Table 1 , items (1), (3), (4) and (6) are all objective reasons. Items (2) and (5) are both subjective, of which Item (5) is also behavioral.

Table 1 Reasons for not downloading online self-study materials

\begin{tabular}{lllllll}
\hline IReasons & $\begin{array}{l}\text { No WIFI or } \\
\text { insufficient } \\
\text { mobile traffic (1) }\end{array}$ & $\begin{array}{l}\text { Oblivion or } \\
\text { inattention (2) }\end{array}$ & $\begin{array}{l}\text { Occasional } \\
\text { downloading due } \\
\text { to the lack of time (3) }\end{array}$ & $\begin{array}{l}\text { No necessary } \\
\text { software to open the } \\
\text { study material (4) }\end{array}$ & $\begin{array}{l}\text { Seldom } \\
\text { going on } \\
\text { line (5) }\end{array}$ & $\begin{array}{l}\text { Mobile phone } \\
\text { being lost (6) }\end{array}$ \\
\hline Numbers & $\mathbf{1 6}$ & $\mathbf{1 5}$ & $\mathbf{1 0}$ & $\mathbf{2}$ & $\mathbf{3}$ & $\mathbf{1}$ \\
\hline
\end{tabular}




\section{No WIFI or insufficient mobile traffic}

Of the 47 students who gave reasons for not downloading the materials frequently for self-study, 16 students attributed this to the absence of WIFI or insufficient mobile traffic. But the fact is before the course started, the teacher provided students with free WIFI access to which they could link their mobile phones freely as long as they approached the designated area. Besides, the university offers students a very cheap Internet connection service: with $5 \mathrm{RMB}$, they can have $10 \mathrm{G}$ downloading traffic monthly, or optionally $0.60 \mathrm{RMB}$ per hour without the limitation of time. For both classes, the materials provided to students only needed a downloading traffic amounting to about $100 \mathrm{M}$ monthly or even less. So this reason given by students for downloading inability is not a well-grounded one.

\section{Oblivion or inattention}

As the second most popular reason, it got 15 users. Interestingly, each time before uploading study materials, the teacher would notify students in class and would remind them to download and use them. So it is difficult to accept it as a reason for their not downloading the materials. Neither is it a convincing excuse.

\section{Occasional downloading due to the lack of time}

A survey of students' timetable indicates that this should be a very important reason for students not downloading the materials and using them. The following is a timetable for Class 1 students in the first term of college life. Class 2 students had a similar one with the same subjects but arranged at different times.

One lesson takes two periods' time. With one period lasting $50 \mathrm{~min}$ and breaks between two consecutive periods, Periods 1 to 4 fill up the morning time from 8 a.m. to 12 a.m., Periods 5 to 8 fill up the afternoon from 2 p.m. to 6 p.m. and Period 9 falls in the evening from 7 p.m. to 8 p.m. Most students study in the weekdays from Monday to Friday and rest during the weekends. But some students have to have their electives on Saturday mornings due to tight course scheduling on the weekdays. Fortunately Class 1 and Class 2 students didn't need to.

Table 2 clearly shows that on average students had 7.2 periods of classroom learning a day. Though courses like Oral English, P.E., Psychological Health, Morality and Law and Military Theories don't need students to prepare before class or give them homework to do after class, students' attendance takes time. So a lack of time, to a large extent, accounted for students' not using the online materials provided by the teacher.

Table 2 The first-term timetable for English major students

\begin{tabular}{|c|c|c|c|c|c|}
\hline Time & Monday & Tuesday & Wednesday & Thursday & Friday \\
\hline Periods $1 \& 2$ & English Listening & Advanced Math & $\begin{array}{l}\text { English Intensive } \\
\text { Reading }\end{array}$ & Sentence Writing & $\begin{array}{l}\text { English Intensive } \\
\text { English }\end{array}$ \\
\hline Periods 3\&4 & $\begin{array}{l}\text { English Intensive } \\
\text { Reading }\end{array}$ & Grammar & English Listening & Advanced Math & Oral English \\
\hline Periods $5 \& 6$ & Oral English & Extensive Reading & P.E & English Phonology & College Chinese \\
\hline Periods 7\&8 & Morality and Law & & Psychological Health & & \\
\hline Period 9 & & & Computer Science & Military Theories & \\
\hline
\end{tabular}


No necessary software to open the study materials, seldom going online and mobile phones being lost

These are clearly just excuses. The study materials were given in usual forms: mp3 or mp4, word documents, and the video clips and microlectures produced by the teacher were presented in the forms of rmvb, wmv or avi which can be opened by smart phones easily. If a smart phone cannot open a material, the solution to the problem will be automatically provided by the phone and the user only needs to follow the instruction to open it.

It's hard to imagine that a college student can't use a smart phone well or seldom goes on line with a smart phone. As a matter of fact, today's young people rely heavily on their phones. According to a study made by the University of Maryland (Alleyne 2011), young people are now so addicted to their mobile phones that it feels like they have lost a limb when they are without them. Worldwide, young people's heavy reliance on mobile phones is already regarded as a behavioral problem, a psychological problem which can affect their mental health (Yen et al. 2009; Vacaru et al. 2014; Zlemaan et al. 2014).

The same problem exists in China and a correlation between young people's mental health and their reliance on mobile phones is also found (Huang et al. 2013; Huang et al. 2013; Sun et al. 2014; Wang et al. 2015) Back in high schools in China, due to the strict control of teachers and parents, most young people couldn't use mobile phones freely, but once in college, they would use them a lot more for various acceptable reasons: the convenience to contact their parents, the need to communicate among themselves, or the requirement of their teachers who need to give them online guidance or send them online materials. Telecoms companies are also found to have their offices established on campus which provide students with cheaper smart phones and more attractive service fees, fully aware that students are not only calculating users of today's cheap phones and services but potential customers of better and more profitable phones and services in the future.

Besides, with internet being so close to people's lives, it's unbelievable that a student only uses a smart phone the way he/she uses a telephone. Given the fact that nowadays notices from various sources like the college, class, a student society, teachers, etc. are always issued online, it's hard to imagine how one can manage not to miss any without the availability of his/her phone for long. And the fact that only one student attributed not downloading to the loss of phone indirectly shows the importance of phones to students. As a matter of fact, college students' obsession with smart phones have aroused so many educators' concern that a casual survey of any comprehensive database will show a vast host of papers on this topic. With all the reasoning taken into account, the three excuses given by students cannot be taken seriously as reasons for not being able to download the materials.

\section{Discussion}

Further reasoning of the downloading rates, the farfetched excuses given by students, the year-long observation of students' downloading habits together with the current situations of teaching and learning pointed out the possible hidden causes of this phenomenon: students' inadaptability to unmonitored e-learning, the restriction of the current teaching syllabus, the lack of desirable communication platform and the 
restriction of teachers' insufficient knowledge of video making techniques as well as programming technology.

\section{Students' inadaptability to unmonitored e-learning Students' low autonomy in using smart phones for self-study}

When resorting to QQ groups to conduct flipped classroom teaching, the teacher overestimated students' ability of self-discipline to study by themselves and their readiness for e-learning as well. Today's youth are good at using mobile phones for information, but so much have they relied on mobile phones for information that phones are required to be handed in first whenever there is an exam in the university where the teaching intervention was attempted. In fact, teachers are worried that smart phones may affect study for many students are found to use them to deal with personal affairs while taking lectures. While smart phones provide students with more convenience to communicate with other people, a quicker way to find out the information they want and more ways for fun, they also distract students from serious business like study and also encourage academic laziness and plagiarism (Wang 2009). Without supervision, students use their smart phones more for fun than for study's sake (Zhou et al. 2011; Dai 2016).

During the year-long observation of students' downloading behaviors, it's found that if not warned by the teacher that the process of their self learning would be checked in class, students would be very reluctant to download the materials for self study. This is evidenced by the teacher's repeated attempts: every time when the teacher warned the students that she would check their home learning in class, a higher downloading rate would occur. For Class 1 students, the frequency of 25 occurred once, 24, once, 22, seven times, 20, twice and 19, four times; for Class 2 students, the frequency of 24 occurred three times, 23, twice, 22, five times and 20, 6 times. Nearly all the high downloading rates coincided with the teacher's preceding warnings. Using QQ chat rooms, it's very convenient for the teacher to upload the necessary materials for students to learn in their spare time, but it also presents a problem: who downloaded the material and who didn't are unknown because the actual users' names wouldn't be shown when downloading took place; what's shown is the total downloading frequency of a material. This is a technical problem within FCM with QQ or Wechat as communication platforms, which can't be solved personally by the teacher and is partially the reason why in general the downloading rates were low: no supervision, no hard work.

Song (2006) points out in her comparative study that Chinese students' learning autonomy is not as high as that of Western European students; 68.15\% Chinese students surveyed agree that it's highly important to plan their learning activities, but only $25 \%$ students who planned could follow their plans and only $38.47 \%$ students could preview their lessons voluntarily. Wang et al. (2012) finds in his assessment study of college students in Henan province, China that college students still heavily rely on classroom teaching and teachers in their pursuit of knowledge and they lacked autonomy in making self-study plans. Song (2006) attributes this to the traditional authoritative role of teachers which led to students' passiveness in learning and heavy dependence on teachers. Besides, teachers' strict supervision throughout students' school years preceding college education is also considered one of the reasons for students' lack of autonomy in learning. As one empirical study reveals (Wang et al. 2006), 
college students' low autonomous learning ability in English results from teachers' excessive control of their English study exerted throughout their school years preceding college education which leads to students' passiveness in study and undesirable reliance on teachers.

Typically, self-regulated learning is seen as a trait that some students possess and those who score high on self-regulation perform well in any educational context regardless of how it is designed (Boevé et al. 2017). However, these ideal students are limited in number and many students lack the ability and desire to learn by themselves. This particularly holds true for Chinese students. Most Chinese students, before their college years, have been busy struggling with the assignments either from the teachers in their schools or from the teachers in their extracurricular tutoring organizations and the heavy workload together with the traditional spoon-feeding teaching method, close supervision and strict control from teachers and parents results in most students having no time nor motivation to explore on their own but barely coping with the teachers' arrangements and the assigned school work. As a result, a good number of students have formed the bad habit of relying heavily on teachers in their pursuit of knowledge. But once in college where self-learning is required, as is shown in this failed case, they would find it difficult to adjust to the new way of learning and showed signs of low autonomy. In addition, to make things worse, many students are unsatisfied with their present majors. When applying for a major to study in university, they were forced to choose the present ones due to a lack of qualifications for desired ones like lower scores and unsuitable physical conditions or simply as the result of parents' choices.

\section{Students' inadaptability to new educational technology}

When resorting to QQ groups to conduct flipped classroom teaching, the teacher also overestimated students' readiness for e-learning as well.

Tools used to aid teaching and learning have changed a lot, especially in recent years. With the development of computer science and information technology, writing on blackboard with chalk is being replaced by slides showing, ppt playing and on-the-spot keyboard typing. Very recently interactive whiteboard which functions as both a screen and a dustless blackboard redefines the meaning of "blackboard". Even the traditional pointer is losing its position in the classroom due to the popularity of a laser one. On the whole, the traditional classroom is 'technologized'.

With the 'technologization' of classrooms, teaching methods and curricular designs are changing as well. But, the problem is while students are taking a fancy to technology for the convenience of having fun, they may feel alienated from it in its application in learning. It is believed that all students are digital natives and therefore, can use the technology well (Prensky, 2001). However, it's debatable that they are ready for e-learning (Valtonen et al. 2009).

Davis (1993) points out that the user acceptance of a new information system, such as online learning is considered the essential factor that determines the success or failure of the system. In fact, in addition to this study, a vast host of relative studies show that students are not naturally ready for e-learning. Piskurich (2003) holds that there are various reasons behind individuals' failure in e-learning environments and often the reason of the failure is that students are not ready for it. Taher Farahat (2012) finds out that although the investment in large number of financial resources and the intensive 
efforts to implement online learning resulted in quantitative growth of e-courses that become online available, the students are reluctant to practice online learning. Hao (2016) also agrees that students are not prepared for flipped learning.

As for the reasons, on one hand, traditionally, young people have depended on human teachers too much and for too long in the course of learning; on the other, they may feel inadaptable to the rising role of new technology in the business of study which is after all a high-demanding job. According to Mar (2013), 40\% of the students surveyed found it difficult to adapt to web-assisted self learning. Hung et al. 2010 specify that students' levels of readiness are high in computer/Internet self-efficacy, and online communication selfefficacy, but are low in learner control and self-directed learning, which partly explains students' low autonomy in using smart phones for self-study as exposed in this failed case.

Technology alienation (Marx and Engels 1980), among other things, also plays a role in students' inadaptability to new educational technology. "I would prefer to have my answer checked by the teacher rather than do it in front of the cold screen," some students in the case said. "My eyes feel dry after staring at the screen for long," other students complained. Technology alienation, a phenomenon in which technology while benefiting humans, also brings harm to humans, has aroused many experts' attention. And the alienation, a phenomenon in which humans feel constrained, suppressed, split, feel meaningless about life, or empty in their heart occurs as a result of technological alienation (Xie and Zhang 2007; Li 2011). Research on students' alienation due to technology alienation is rarely found, or done in the aspect of students' readiness for e-learning. But this sort of alienation indeed exists. At least, it is indisputable that physically, long term staring at the screen harms the eyes a lot. And intensive use of mobile phones is believed to affect health, causing headaches and even brain tumours (Kan and Lyon 2008). For sensitive students, though, small in number in these two classes, how to reduce their feelings of alienation is still a big problem.

\section{Students' lack of necessary free time due to the tight course arrangement}

From the the timetable of Class 1 , we can see students in this class had a very tight course schedule in the first term of their first school year. In the following coming terms and years, they continue to have very tight course arrangements until in the last term when they will be busy with social practice and thesis writing and defence. The timetable of Class 1 shown above includes core courses and electives aimed at a whole class, not individuals. Table 3 shows the timetable for students in the fifth term of their college life, who are two grades higher than Class 1 students mentioned above.

Students in the third year have a less tight timetable than they did in their first two years when more basic courses aimed at language skills are provided. Starting from the first term of the third year, students will have more professional courses which are highly academic and thus time-consuming. However, except Consecutive Interpretation, all the other courses are compulsory in nature; in this sense, English major students even when having a less tight schedule will have at least 4.8 periods a day excluding department-scale and University-scale electives aimed at individuals. Consecutive Interpretation is a department-scale elective open to the third-year English majors only. There are also University-scale electives open to all students of the same grade, regardless of their majors. These courses are only shown on students' individual timetables. 
Table 3 The fifth-term timetable for English major students

\begin{tabular}{|c|c|c|c|c|c|}
\hline Time & Monday & Tuesday & Wednesday & Thursday & Friday \\
\hline Periods $1 \& 2$ & $\begin{array}{l}\text { English for Special } \\
\text { Purpose }\end{array}$ & $\begin{array}{l}\text { Oral } \\
\text { Interpretation }\end{array}$ & $\begin{array}{l}\text { Translation Theories } \\
\text { and Practice }\end{array}$ & $\begin{array}{l}\text { Advanced Reading } \\
\text { in English }\end{array}$ & $\begin{array}{l}\text { Second Foreign } \\
\text { Language }\end{array}$ \\
\hline Periods $3 \& 4$ & $\begin{array}{l}\text { Advanced Reading } \\
\text { in English }\end{array}$ & & $\begin{array}{l}\text { Second Foreign } \\
\text { Language }\end{array}$ & & $\begin{array}{l}\text { British and American } \\
\text { Literature Studies }\end{array}$ \\
\hline Periods $5 \& 6$ & Oral English & Linguistics & & & British Opera \\
\hline Periods $7 \& 8$ & $\begin{array}{l}\text { International } \\
\text { Business }\end{array}$ & & & $\begin{array}{l}\text { Consecutive } \\
\text { Interpretation } \\
\text { (selective) }\end{array}$ & Writing in English \\
\hline Period 9 & & & & & \\
\hline
\end{tabular}

A further survey of the timetables of students of other majors in this university also shows that they have equally tight basic-course arrangements in their first two years and slightly less tight schedules which encompass more academic and professional courses in their later years and which show on average about 5 periods of class learning per weekday.

In fact, college students in China typically have tight course schedules. Xiao (2001) made a survey of the term timetables of six departments in her university and found that students on average had 26 periods of classroom teaching per week. Hu et al. (2011) point out that the ten universities in Beijing which they compare with their own university for the correlation between weekly period numbers and chances of students falling in love are found to have on average 29.5 periods of classroom teaching per week and five universities surpass 30 periods and their own university, though having less periods of classroom teaching a week, has 22 periods on average. According to Yu (2014), "Students majoring in business administration in Fudan University in the first and second terms on average have more than 25 periods of classes and 18 periods in the following terms...Such a tight course schedule gives students a very heavy workload and greatly reduces their free time of independent learning and exploration". Mar and Zhang (2011) point out the root of the phenomenon "Universities in China basically follow a teacher-fronted or manager-fronted institutional system in which students learn and lead a campus life while confined to it. This system ignores the idea of student-orientation and students' need for free overall development and the freedom of learning is regarded as unnecessary and therefore is not mentioned at all."

Such a system is unlikely to change in a short period of time and students' weekly workload will continue to be high. With such a heavy compulsory workload, students' interest in leaning by themselves after class cannot be expected to be high, and to make it worse, as is shown in this case, when self-discipline was the only means of supervision, it's really difficult to flip the class.

\section{The lack of desirable public communication platform}

With the current public communication platform provided by the school, teachers and students can visit the school website freely, searching for, uploading and downloading information related to their work and study such as teaching syllabus, class information, curriculum arrangements, specific timetables, ect. But it doesn't provide a platform where teachers and students can interact freely, where teachers can assign students tasks and check their fulfillment and students can hand in their papers, put 
forward questions and discuss them with their teachers or other students. With the aid of QQ and Wechat, teachers and students can upload and download materials quite freely and can have discussions freely. But the limitation of both QQ and Wechat which are commonly used by teachers and students as means of spare-time communication is that they don't provide the function of supervision. In the failed case, that students' use of self-study materials before class couldn't be guaranteed is mainly due to the lack of supervision from teachers. With QQ or Wechat as a communication platform, who downloaded the material and who didn't are unknown because the actual users' names are not shown when downloading took place; what's shown is the total downloading frequency of a material.

Top universities in China and universities which receive strong financial support from the government are either technically competent enough to develop their own communication platforms which can better serve their purposes or are financially strong enough to purchase the platforms from software companies to meet their needs. In either case, techniques and finance play a key role in the construction of a digital campus.

In fact, large-scale 'informationization' in the field of education hasn't existed for long. It was not until in March, 2006 that General Office of CССРC clearly stated in No. 11 document of the year the need to speed up 'informationization' in education and scientific research and regarded it as one of the strategic priorities of national information development. And again it clearly called for the acceleration of educational 'informationization' in the 19th chapter of Outline of the National Medium and Long Term Education Reform and Development Plan(2010-2020), a programmatic document issued in March, 2010. In recent years, great efforts have been made on the 'informationization' of colleges and universities, but most colleges and universities are still lacking in a desirable communication platform between students and teachers, and the present platform provided by the university cannot meet the requirement of flipped classroom teaching.

Besides, as students still rely on parents financially, the present charge for the internet service still looks high to them. This also greatly hampers them from using the internet for the sake of study. But if this expense is transferred onto the higher learning institutions, it will be a great financial burden to them for the lack of enough financial support from the government.

\section{Teachers' lack of enough knowledge and techniques concerning computer application and programming}

Technological alienation can affect every one. While students may feel ill at ease learning through an electronic device, teachers may feel the same when teaching with the aid of a computer (Zhao and Cziko 2001; Bawer and Kenton 2005; Nikian et al. 2013). In the failed case, while the teacher took students as her subjects, wasn't the teacher also a subject of the case and clearly showed a lack of understanding of FCM?

To flip a classroomroom, while some scholars have argued that technology is not a necessary element for self-learning before class time, undeniably, it is the easiest way to present teachers' instruction of the learning contents (Hwang et al. 2015). FCM places a high demand on teachers' knowledge of computer science and information technology, which is a challenge for a vast number of teachers. Aside from the 
consideration of the charges of software programs like Camtasia Studio which was free to use in its initial stage but later charges quite high, the making of microlectures released to students before class is in itself a time-consuming and energy-exhausting job. To make a microlecture, teachers have to spend a lot of time collecting appropriate materials, designing ways of presenting them, recording the lecture and editing the lecture, the quality of which cannot therefore be guaranteed just because of effort being made.

In the failed case, the teacher devoted substantial time and effort to making microlectures and designing class activities, but failed to get a warm response from students. The immediate high downloading rate of 25 for the first lesson shows that students were interested in and curious about the microlecture made by the teacher but the following low downloading rates clearly show students' loss of interest in the materials. In addition, poor quality of the microlectures also accounts for the failure, though it's not mentioned by students, presumably out of respect. As a teacher who aspired to further embrace e-teaching, wasn't the teacher also a subject who clearly showed insufficient technical competence?

Apart from making microlectures, to achieve desired self-learning result, supposing students do download the microlecture for reasons of curiosity, high self-discipline or supervision from teachers, to help students understand the lecture correctly teachers need to give students questions for self-check. Since students' proper understanding of the released material is crucial to the successful execution of class activities, the check on their self-study efficiency is very important. Here arises the problem: how? When teachers cannot count on every student's discipline to do the job themselves, teachers need to either make self-check an interesting thing to do by designing and programming reflection questions, or interact with students one by one before class with the aid of QQ or Wechat; otherwise they cannot guarantee the desired self-learning effect for each student, nor can they smoothly and swiftly move on to the next teaching procedure in class. Interacting with students one by one would be extremely timeconsuming for teachers, especially if it's a large class. The simplest method is that students check their understanding by following a programmed question-and-answer procedure themselves and do corresponding programmed follow-up exercises when making some mistakes, i.e. through Online Instant Response System (Hao 2016), but then teachers would face the same question "how", for the lack of necessary computer programming knowledge. In the failed case, the teacher relied on students' autonomy to do the work, which turned out to be unrealistic.

Of the four possible reasons for the failure, the lack of a desirable communication platform and teachers' lack of adequate knowledge of software usage and information technology are more crucial reasons. Without a desirable communication platform, teachers cannot keep track of students' self-learning, and thus is oblivious as to how well the whole class have prepared and who have or haven't prepared well, which makes the smooth implementation of class activities uncertain. Teachers' lack of enough programming knowledge and knowledge of information technology hinders them from making high-quality microlectures which can interest and attract students, and also renders them unable to freely generate questions and answers which can help check students' comprehension of preparatory materials and address their mistakes if there are any. TAL's successful application of FCM is strong evidence shown in the following section. 


\section{A successful case of FCM in China}

While FCM is still in the bud for most higher institutions in China, some private educational institutions have introduced it into their course designs. Among them is TAL Education Group known as Tomorrow Advancing Life which provides afterschool tutoring services for Chinese students from primary schools to high schools. The author chanced to notice it and observed its way of teaching from the perspective of a sensitive university teacher.

\section{The design of FCM for one lesson}

The train of thoughts of TAL for the design of one lesson can be represented by the chart as shown in Fig. 3.

As is typical of FCM, one lesson is designed in three steps: before class, in class and after class. Take math for example, before each class begins, TAL will upload a microlecture to its students for them to study in their spare time. Students are free as to when and where they will learn through the microlecture, but they must do it before the class. After watching the microlecture, they are given exercises for self-check and if they make a mistake, corresponding exercises are given, and if they are wrong again, more exercises will be given until they can answer the questions correctly. If they want to, they can click to watch a microlecture on this question.

At the beginning of every class, to further guarantee students' correct understanding of basic knowledge which they will encounter in the class, the teacher gives them a pre-class quiz and expounds questions which are wrongly answered. In class, teachers no longer focus on the explanation of basic knowledge, but various math problems concerning this bit of knowledge. Before the end of each class, the teacher gives students another quiz to check their class learning effect and expound questions which most students wrongly answer. Neither the pre-class quiz nor the end-class quiz takes a long time, each lasting ten minutes at the most, for students are required to hand in their answers on line within ten minutes and their answers are immediately checked by TAL's unique internet teaching system (i.e.the Online Instant Response System). Simultaneously, an analysis report based on students' performance is generated automatically and shown to the teacher who then is able to focus on the wrongly answered questions. To inspire students, the system also presents the image pictures of the first three students who correctly answer all the questions and distinguishes them respectively as the

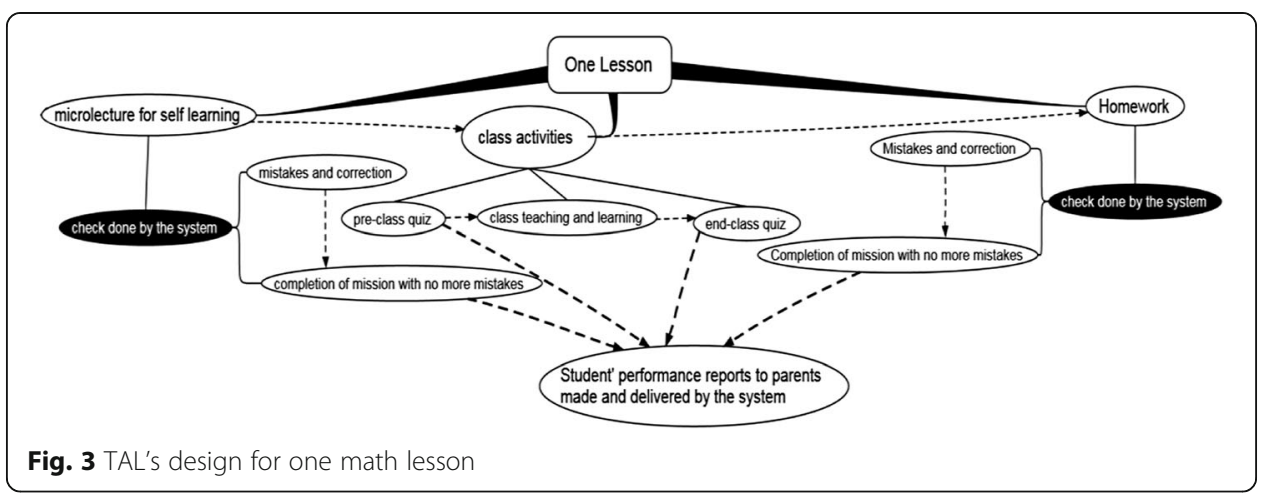


first, second, and third-prize winners, with the names of other students who make the same achievement but at lower speeds following (This practice may be arguable in some cultures but based on long-term observation of the students which the author chanced to make, they showed no aversion to it, for two reasons: first, the questions were basic enough so that most students could answer them correctly and second, they took it as an opportunity to 'show off').

This system not only enables teachers to tell easily what questions need further instruction but makes learning competitive and attractive to students for they can not only get the honor of having their names shown publicly but rewards from their teachers if they perform well in class. After each class, homework will be assigned to students and students are asked to photograph their homework and hand it in on line. If students make a mistake, they have to correct their mistake by doing more exercises and the process goes on until they give right answers. If they cannot figure out the reason for their mistake, they can watch the microlecture attached which tells them the right way to solve the math problem.

The whole learning and teaching activities for one lesson are closely linked one after another and made into a game-like practice-students have to accomplish one mission before they can take another. If they don't, the system will automatically send a prompt to the parents by email, upon which parents will urge their children to finish the unfulfilled task. For students who finish the whole procession of activities, they will get rewards from the system as in a computer game.

In the whole process, the teacher and technology cooperate very well. The teacher still plays the major role in the teaching process with technology assisting alongside.

\section{The enlightenment of TAL's success}

TAL has become a very successful extracurricular tutoring organization in all major cities in China. Apart from its commercial success as being the leading private tutoring organization in China, pedagogically, it's also a huge success, especially with its math teaching which has the longest history and is the most fully developed one compared with other programs concerning physics, chemistry, etc. Besides its usual model of teaching in which students study in the classroom with their teacher, it's also exploring new ways of teaching, like teacher-and-assistant model and entirely online model. In the teacher-andassistant model, students still study in the classroom but learn from the screen where a teacher's image is shown and his/her teaching is broadcast, and their learning will be aided by an assistant whose function is to organize and supervise. In its nature, it's a form of online model, but aided by an assistant. In the entirely online model, students study at home, learning at the same time as students studying in a classroom, still with the aid of an iPad. The two new models mainly cater to highly-disciplined students, especially the last one aimed at students who want to spare time on commute.

From the perspective of a university teacher who has become extremely sensitive to any form of FCM, in terms of the integration of teaching and technology, TAL has gone much farther than most universities including the one the author is working with. There are similarities between TAL and her failed case and, difference which leads to the difference in results. They can be generalized as shown in Table 4. 
Table 4 Similar and different factors in implementing FCM

\begin{tabular}{lllllll}
\hline & $\begin{array}{l}\text { Students' } \\
\text { workload }\end{array}$ & $\begin{array}{l}\text { Degree of } \\
\text { flipping }\end{array}$ & $\begin{array}{l}\text { Teachers' } \\
\text { competence }\end{array}$ & $\begin{array}{l}\text { Students' age } \\
\text { and disciple }\end{array}$ & $\begin{array}{l}\text { Scale of } \\
\text { implementation }\end{array}$ & Technical support \\
\hline TAL's FCM & same & same & same & unfavourable & unfavourable & favourable \\
The Failed FCM & same & same & same & favourable & favourable & unfavourable \\
\hline
\end{tabular}

The similarity between TAL's students and the students of the failed case

TAl's students are pupils and middle-school teenagers. On the whole, they are much younger than the students of the failed case. Despite the age difference, they share much in common: both have a tight course schedule. TAL's students have a full day schedule from Monday to Friday, and during the weekends, they attend various extracurricular activities including academic ones in various centers like TAL. Younger and generally less-disciplined than university students, they lead an equally busy life if not busier. But faced with such students, TAL's teachers can always successfully lead the much younger and less-disciplined learners to finish the extra learning tasks alongside their heavy schoolwork, on a large scale and year after year.

\section{The similarity between TAL's FCM and FCM of the failed case}

Teaching by flipping a classroom is not something new, but it's been done in a traditional way of flipping, not in the way of FCM in question (Strayer 2007). With FCM a teacher flips a classroom with the integration of modern information technology and computer science.

Neither does FCM necessarily mean great effort must be put into it. It depends on the extent to which one flips. If one totally flips a classroom, a huge amount of effort is involved, but if he/she only flips the classroom partially, the amount of work decreases correspondingly (Zhu and Yu 2017).

In both cases, only partial flipping is involved with only the very basic part of the teaching contents assigned to students and the bulk of teaching contents still handled in the traditional way in which teachers are still the center of information dissemination and main source of solutions to questions.

\section{The similarity between TAL's teachers and the teacher of the failed case}

In either case, the teacher takes a serious attitude to what's taught and has tried to be well prepared for class teaching activities.

Though TAL is a private tutoring organization, it's said to have a strict procedure of teacher selection and based on the author's observation, TAL's teachers are very familiar with their teaching contents, clear about each teaching activity and fully aware of the importance of creating a favorable class environment by being fair, friendly and encouraging to young learners. And the author who attempted this teaching intervention but failed has a teaching experience of 16 years and thus has gathered considerable educational skills.

\section{The difference leading to different results}

With so many similarities, there are also differences between the two cases. In terms of the scale of implementation, TAL's teaching with FCM has been implemented on a far larger scale, which increases the difficulty of implementation and the failed case, on a far smaller scale, which should have been much easier to handle. In terms of age and discipline, TAL's students who are pupils and middle school students, are much 
younger than students in the failed case and compared with university students, pupils and middle school students should have less self-discipline characterized by their age.

Despite the similarities and unfavorable differences, TAL's teachers succeed in their teaching with FCM, whereas the author failed in a similar practice. The big difference, as can be discovered from its course activities, is that TAL's FCM is propelled by a powerful online communicative system and a teacher-friendly Online Instant Response System, whereas, the teacher of the failed case is solely dependent on a limited knowledge of modern technology which is far from enough and a far less satisfactory communication platform whose function it seems is mainly to send study materials to students. Students, on the contrary, seldom use this system to ask questions.

From Fig. 3, we can see TAL's class design is systematic and progressive with activities before, in and after class linked one to another smoothly. The communicative system together with its app is so powerful that it can not only set tasks, check students' work, make them correct mistakes, but supervise students by enlisting the help of their parents and encouraging them to move forward by rewarding them for their effort. In fact, with this system, students' inadaptability to e-learning is not a problem worth considering. The reasons are at least fourfold. First, the system is user-friendly- a kindergarten pupil can easily learn to manage it; second, the system is prompt, able to provide students (and teachers) an immediate feedback on their work; third, the system is fun, encouraging students to move from one task to another, and last it's compulsive, using technology to compel students to finish one task before they can move up to another and to have their parents give them a nudge when they delay in their work. The compulsive nature of TAL, though tyrannical in operation, contributes a lot to its success. Apart from the heavy workload students face, personal traits or weaknesses like procrastination, laziness, lack of initiative, and lack of enough interest may all hinder their study. Those problems exist in pupils, middle school students and university students alike and have greater impact on teaching with FCM than teaching in a traditional way. In this regard, supervision and management of students is part and parcel of FCM in current situation.

To better cope with the nature of students, with the support of SPOC and its app called "Rain class", Zhu and Yu (2017) of Tsinghua University divided their students who took the same course into three classes in order of personal initiative and interest. With the highly interested students, they totally flipped the classroom with less supervision and management but with more projects and applications; with the less interested students, they partially flipped the class and with the least interested students, they reduced the teaching contents, lowered the degree of difficulty and also partially flipped the class. With the the latter two groups, they devised more activities to arouse students' interest and to ensure their attendance and participation. In the end, all groups of students showed their satisfaction with this course. Yu attributed a lot of his success to the powerful communicative system and the affiliated app he used in his tour lectures on Student-Centered Teaching Based on Application Modes of MOOC Resource. According to $\mathrm{Yu}$, this system together with its app provided great fun (with the app, Yu designed interesting interactive class activities which greatly motivated students), instant feedback on their work, discipline formed without students' awareness, supervision and management on the teacher's part, all of which ultimately led to effective learning. 


\section{The enlightenment of TAL's success on current teaching}

What can be learned from TAL's success are twofold: on the one hand, university teachers need the backup of a more powerful communicative system than what they currently have; on the other, they need to keep pace with the times. They need to arm themselves with modern educational technology.

When flipping a classroom in a traditional way without much technical support, to make sure that students do work on their assignment, a teacher has to rely on human qualities like high self-discipline, high motivation, initiative and personal charisma. But the reality is that these qualities do not exist in every student and nor does personal charisma in every teacher. So the teacher often has to resort to strict management which has to be acknowledged and accepted by students and which surely involves a great deal of time and labour as it is done entirely physically.

But modern educational technology has brought great change and benefits. TAL's communication platform and Online Instant Response System create a smart learning environment for students and provide a solid technical support for teachers to flip classes. Apart from the issue whether such young students should have such a heavy workload which has become a heated educational argument and social issue and regardless of TAL's original aspiration, for commercial success, for the improvement of students' academic performance, or for both, its popularity among students and parents and its success as a private establishment shows, pedagogically, a success of the integration of education and technology. TAL's success together with many others' successes like Pro. Yu's all show the necessity of having a powerful communication platform, or further, the need of building a smart classroom, a smart school, a smart learning and teaching environment for students and teachers.

Teachers of TAL are not working alone. Besides many other teachers of the same subject, they are standing side by side with a powerful system and affiliated app which, in turn, have teaching assistants, a curriculum research team and software development team in support. Unlike TAL's teachers, individual university teachers have none of these. And they usually take charge of a course or a program alone with no one else to resort to. While urging the school management to speed up the construction of "smart learning environment", which is an unavoidable trend, they should also acquire as much modern educational technology as possible. After all, a smart learning environment can only create a favorable environment for teachers, specific details are all up to individual teachers to decide like how to design a flipped classroom, to what degree, what materials to prepare and present before, in, or after a class, in what form, in which way, how to motivate less interested students, how to maintain students' passion for this subject for long, and how to estimate their effort. The solutions do not only depend on a teacher's own professional and educational knowledge and skills, but also the knowledge and skills of modern technology. Traditionally, it's enough for a teacher to have the first two kinds to teach well, but with the development of technology and its influence on education, the last kind exerts a substantial influence on an individual teacher's teaching, particularly, teaching with FCM.

\section{Conclusion}

FCM as a radical approach to teaching and learning is reforming traditional ideas of teaching and learning, traditional roles of teachers and students as well as the old ways 
of curriculum arrangement, course design, knowledge transmission, learning and teaching habits, etc. Due to its obvious advantages, it's attracting more and more teachers who are eager to try this new way of teaching but may be doomed to disappointment with the result for the lack of necessary conditions and preparations.

In the discussed case, the attempt at FCM made with great enthusiasm at the beginning turned out to be a great failure in the end. Small-scale as it is, it is of representative nature in terms of its ordinariness in view of hardware and software facilities, enrollment quality and in view of the conductor's expertise in modern educational technology as well as understanding of FCM, and what's behind the failure is of some value.

Promising as it is as a new approach to education, FCM poses a challenge to the old teaching and learning: it places high requirements on the hardware facilities of teaching and learning environments, on the technical knowledge and application of teachers and the cooperation of students as well; it also calls for a change in the current curriculum design so as to allow students more free time to learn themselves. Apart from the problems of students' inadaptability to e-learning and tight course schedules for students, the lack of a desirable communication platform and problems concerning details like how to guarantee desirable accomplishment of the preparatory tasks of all students and how to produce instructive and attractive microlectures for students as well as how to check students' intake of study materials are all great challenges to university teachers. And the solutions to these problems, as the paper reveals mainly lie in the further construction of smart teaching and learning environments as well as individual teacher's study and application of modern educational technology.

While FCM points out a trend towards an individual-oriented style of teaching and learning in the future, it currently proves to be a highly-demanding way of teaching for most university teachers. As a result, when it is carried out successfully in some teachers' classes, it may not be so in others', for the lack of appropriate conditions, preparations and a correct understanding of this approach.

Frustrating as the research findings are to many university teachers, the results may not hold true for others. The failed case was carried out in an average university in China. Though the discoveries made with the attempt of FCM in this school are representative of many average universities in China, in top universities where the qualities of enrollment are different, and/or the online communication platforms are better, the findings may not be able to hold true, nor can the findings hold true in regions where educational theories and approaches are far more advanced and where FCM is going much deeper. Besides, due to the small size of data and the deductive nature of reasoning, more attempts are needed to further verify the findings.

Acknowledgments

Not applicable

Funding

Not applicable

Availability of data and materials

Main data and materials are provided in a separate file.

Author's contribution

The paper and the research on which the paper is based on are of individual effort. 
Author's information

Not applicable

Competing interests

The author declares that he/she has no competing interests.

\section{Publisher's Note}

Springer Nature remains neutral with regard to jurisdictional claims in published maps and institutional affiliations.

Received: 2 September 2017 Accepted: 22 January 2018

Published online: 14 February 2018

\section{References}

R Alleyne, The young generation are addicted to mobile phones. English Salon (7), 44-45 (2011) Retrieved Jan. 2, 2018, from http://kns.cnki.net/KCMS/detail/detail.aspx?dbcode=CJFQ\&dbname=CJFDN0911\&filename=YYSS201 107021\&uid=WEEvREcwSIJHSIdRa1Fhb09jSnZpSU1GdVFVNS9sQ1FEWjlLdmFSYUhGOD0=\$9A4hF_YAuvQ5obg VAqNKPCYCEjKensW4ggl8Fm4gTkoUKalD8j8gFw!!\&v=MTA3ODJDWJMS2ZadVpORkNuaFVMdkIQRFRZZmJHNEg 5RE1XSTIIWIISOGVYMUX1eFITNORoMVQzcVRyV00xRnI=

W Baker, The classroom flip: Using web course management tools to become the guide by the side. 11 international conference on college teaching and learning, 9-17 (2000) Retrieved Jan. 2, 2018, from http://works.bepress.com/j_ wesley_baker/21/

J Bawer, J Kenton, Toward technology integration in schools: Why it isn't happening. J. Technol. Teach. Educ. 13(4), 519-546 (2005) Retrieved Jan. 2, 2018, from https:/www.highbeam.com/doc/1G1-138483291.html

AJ Boevé, RR Meijer, et al., Implementing the flipped classroom: An exploration of study behaviour and student performance. High Educ 74(6), 1015-1032 (2017)

C Chiang, C Chen, Modified flipped classroom instructional model in "learning sciences" course for graduate students. The Asia-Pacific Education Researcher 26(1-2), 1-10 (2017)

CUAA-Team of China University Evaluation (2017). Best University Ranking List of Shaanxi Province. 艾瑞深2017陕西省 最好大学排名http://www.cuaa.net/paihang/news/news.jsp?information_id=132061. Accessed 9 April, 2017.

JB Dai, Empiral research of the effects of mobile phone media on college students autonomous learning in "internet+" era. “互联网+"时代手机媒体对大学生自主学习影响的实证研究. Heilongjiang researches on higher education 黑龙江高教研究 268(8), 132-136 (2016) Retrieved Jan. 1. 2018, from http://d.g.wanfangdata.com.cn/Periodical_ hljgjyj201608039.aspx

FD Davis, User acceptance of information technology: System characteristics, user perceptions, and behavioural impacts. Int J Man- Machine Stud 38(3), 475-487 (1993)

T Farahat, Applying the technology acceptance model to online learning in the Egyptian universities. Procedia-Social Behav Sci 64(9), 95-104 (2012)

JD Fletcher, DE Hawley, PK Piele, Costs, effects, and utility of microcomputer assisted instruction in the classroom. Am Educ Res J 27, 783-809 (1990)

General Office of the CPC Central Committee. (2006). National informatization development strategy From 2006 to 2020. 2006-2020 年国家信息化发展战略. http://www.gov.cn/test/2009-09/24/content_1425447.htm. Accessed 8 Apr 2017

YW Hao, Exploring undergraduates' perspectives and flipped learning readiness in their flipped classrooms. Computers in Human Behavior 59, 82-92 (2016) Retrieved Jan. 2, 2018, from http://www.sciencedirect.com/science/article/pii/ S0747563216300401

KK He, The development of flipped classroom in China in view of its nature. 从翻转课堂的本质看翻转课堂在我国的 未来发展. E-education Research.电化教育 255(7), 5-16 (2014). https://doi.org/10.13811/j.Cnki.Eer.2014.07.001

X Hu et al., Study on the correlation between weekly period number and students' likelihood of falling in love. 关于大学课程设置(课时方面)对大学生恋爱率影响的探究. China Education Innovation Herald. 中国科教创新导刊 (4), 66-67 (2011) Retrieved Jan. 2, 2017, from http://kns.cnki.net/KCMS/detail/detail.aspx?dbcode=CJFQ\&dbname= CJFDN0911\&filename=GWDT201104055\&uid=WEEVREcwSIJHSIdRa1Fhb09jSnZpSU1GdVFVNS9sQ1FEWjILdm FSYUhGOD0=\$9A4hF_YAuvQ5obgVAgNKPCYCEjKensW4ggl8Fm4gTkoUKalD8j8gFw!!\&v=MDk5NTIKSW pyUGVyRzRIOURNcTQ5QVIZUjhIWDFMdXhZUzdEaDFUM3FUcldNMUZyQ1VSTEtmWnVadEZ5RG1WTDM=

H Huang, L Yu, SH Guo, The relation between college students' reliance on mobile phones and the five types of personalities. 大学生手机依赖与大五人格的关系. Chinese journal of school Health.中国学校卫生 34(4), 414-419 (2013) Retrieved Jan.2, 2018, from http://d.g.wanfangdata.com.cn/Periodical_zgxxws201304011.aspx

H Huang, CY Zhou, L Yu, The relation between college students' reliance on mobile phones and their mental health. 大学生手机依赖与心理健康的关系. Chinese journal of school Health.中国学校卫生 34(9), 1074-1076 (2013) Retrieved Jan.2, 2018, from http://d.g.wanfangdata.com.cn/Periodical_zgxxws201309018.aspx

ML Hung, C Chou, CH Chen, ZY Own, Learner readiness for online learning: Scale development and student perception. Computers and education (55), 1080-1090 (2010)

GJ Hwang, CL Lai, SY Wang, Seamless flipped learning: A mobile technology enhanced flipped classroom with effective learning strategies. J Comput Educ 2(4), 449-473 (2015)

S Kan, E Lyon, Cellular phone use and brain tumor: A meta-analysis. J Neuro-Oncol 86(1), 71-78 (2008)

MF Li, Teachers' development viewed from the perspective of technology. 技术视野下的教师发展论. Beijing science press. 北京科学出版社, $2011: 93$ (2011) Retrieved Jan. 2, 2018, from http://product.dangdang.com/21051123.html.

TQ Mar, YQ Zhang, Implementation of learning freedom and system construction- concurrently on the cultivation of innovative talents. 学习自由的实现及其制度建构一兼论创新人才的培养. Educational Research.教育研究 379, 50-54 (2011) Retrieved Jan. 2, 2018, from http://kns.cnki.net/KXReader/Detail?dbcode=CJFD\&filename= JYYJ201108013\&uid=WEEvREcwSIJHSIdRa1FhcEEORVZXZnU1U2MvQzFMYOIRVFZ0cGRhSTUwST0=\$9A4hF_ YAuvQ5obgVAqNKPCYcEjKensW4ggl8Fm4gTkoUKalD8j8gFw!! 
K Marx, F Engels, Complete works of Marx and Engels. 马克思恩格斯全集. People's publishing house. 人民出版社, (23) 408-553, (42) 89-103.(1980) Retrieved Jan. 29, 2018, from http://marxists.anu.edu.au/chinese/PDF/ME-old.htm. NB Milman, The flipped classroom strategy: What is it and how can it be used? Distance Learning 9(3), 85-87 (2012) Retrieved Jan. 2, 2018, from http://connection.ebscohost.com/c/articles/99397256/flipped-classroom-strategy

Nikian, S. et al.(2013). Malaysian teachers' perception of applying technology in the classroom. Sciences. (103), 621-627. Retrieved Jan. 2, 2018, from http://www.sciencedirect.com/science/article/pii/S1877042813038251

Novembe, A., Mull, B. (2012) Flipped Learning: A Response to five Common Criticisms. November Learning. http://novemberlearning.com/assets/flipped-learning-a-response-to-five-common-criticisms.pdf.

GM Piskurich, Preparing learners for e-learning. San Franciso: John Wiley \& Sons. From Prensky, M(2001). Digital natives, digital immigrants Part1. On the Horizon. 9(5), 1-6 (2003)

GY Qin, GJ Zhu, Prerequisites of FCM in Higher Vocational Schools. 高职院校推行“翻转课堂”教学模式的条件研究. Communication of Vocational Education (18), 50-52 (2014) Retrieved Jan. 2, 2017, from http://kns.cnki.net/KCMS/ detail/detail.aspx?dbcode=CJFQ\&dbname=CJFD2014\&filename $=$ ZJTX201418018\&uid=WEEvREcwSIJHSIdRa 1Fhb09jSnZpSU1GdVFVNS9sQ1FEWjILdmFSYUhGOD0=\$9A4hF_YAuvQ5obgVAqNKPCYcEjKensW4ggl8Fm4g TkoUKalD8j8gFw!!\&v=MjQ0NzVuVnJyQVB5ZmZkckc0SDIYTnA0OUViSVI4ZVgxTHV4WVM3RGgxVDNxVHJXTTF GckNVUkxLZIp1WnRGeUQ=

Rui et al., Friend or foe? Flipped classroom for undergraduate electrocardiogram learning: A randomized controlled study. BMC Med Educ (2017). https://doi.org/10.1186/s12909-017-0881-8

TH Song, Promoting learner autonomy in English classroom teaching. 英语课堂教学中自主学习能力的培养. Journal of Shanxi agricultural University 山西农业大学学报 (5), 415-417 (2006) Retrieved Jan. 2, 2018, from http://d.g. wanfangdata.com.cn/Periodical_sxnydxxb-shkx200604025.aspx

J Strayer, The effects of the classroom flip on the learning environment: A comparison of learning activity in a traditional classroom and a flip classroom that used an intelligent tutoring system. dissertation (2007) Retrieved Nov.17, 2017, from https://etd.ohiolink.edu/pg_10?201760078760444::NO:10:P10_ETD_SUBID:66065

DL Su, Empirical study of FCM in English teaching in higher vocational Schools. 高职英语翻转课堂教学实证研究. Journal of language and literature Studies. 语文学刊 (6), 111-113 (2016) Retrieved Dec. 18, 2017, from http://kns. cnki.net/KXReader/Detail?dbcode=CJFD\&filename=YWWY201606050\&uid=WEEvREcwSIJHSIdRa1Fhb09jSnZ pSU1GdVFVNS9sQ1FEWjLdmFSYUhGOD0=\$9A4hF_YAuvQ5obgVAgNKPCYcEjKensW4ggl8Fm4gTkoUKalD8j8gFw!!

BC Sun, The development of internet in China. 因特网在中国的发展. Science and Technology for China's Mass Media. 中国新闻科技 (12), 17-21 (1999) Retrieved Jan. 2, 2018, from http://kns.cnki.net/KCMS/detail/detail.aspx?dbcode= CJFQ\&dbname=CJFD9899\&filename=CMKJ199912006\&uid=WEEvREcwSIJHSIdRa1Fhb09jSnZpSU1GdVFVNS9sQ1FE WjlLdmFSYUhGOD0=\$9A4hF_YAuvQ5obgVAgNKPCYCEjKensW4ggl8Fm4gTKoUKalD8j8gFw!!\&v=MDgxMjl EaDFUM3FUcldNMUZyQ1VSTEtmWnVadEZ5RGhWcjdNSmIEQVpMS3hGOWpOclk5RIllvUjhIWDFMdXhZUzc=

JW Sun, L Li, C Lin, et al., College students' mobile phone dependence and Loneliness. 大学生手机依赖综合征及与孤 独感关系. Chinese journal of public health. 中国公共卫生 30(9), 1147-1150 (2014). https://doi.org/10.11847/ zgggws2014-30-09-12

AL Tian, Inproving the cultivation model of professional students with the aid of MOOC. 借助慕课改善人才培养模式 Primary and secondary school E-teaching. 中小学信息技术教育 (2), 13-15 (2014). https://doi.org/10.3969/j.issn. 1671-7384.2014.02.004

MA Vacaru, RM Shepherd, J Sheridan, New Zealand youth and their relationships with mobile phone technology.Int J Ment health. Addiction 12(5), 1-13 (2014)

T Valtonen, J Kukkonen, P Dillon, P Vaisanen, Finnish high school students' readiness to adopt online learning: Questioning the assumptions. Comput Educ 53(3), 742-748 (2009)

Wang, C.I.(2009). The influence of new media on college students'life, study and thinking. 新媒体对大学生生活、学 习和思想的影响. Theoretical Front in Higher Education. 高校理论战线. (7), 40-41. Retrieved Jan. 2, 2018, from http://kns.cnki.net/KCMS/detail/detail.aspx?dbcode=CJFQ\&dbname=CJFD2009\&filename=GXLL200907010\&uid= WEEvREcwSIJHSIdRa1Fhb09jSnZpSU1GdVFVNS9sQ1FEWjILdmFSYUhGOD0=\$9A4hF_YAuvQ5obgVAgNKPCY cEjKensW4ggl8Fm4gTkoUKalD8j8gFw!!\&v=MjE2MjR1eFITNORoMVQzcVRyV00xRnJDWJJMS2ZadVpORkNua1VMekl JalhIWXJHNEhOak1XSTIFWkISOGVYMUW=

HB Wang, YK Tang, HT Xu, Inhibition control characteristics in college students with different mobile phone addiction. 不同手机依赖程度大学生的抑制控制特. Chinese mental health journal. 中国心理卫生杂志. 29(3), 226-229. (2015). https://doi.org/10.3969/j.issn.1000-6729.2015.03.012

TX Wang et al., Assessment of the learning autonomy of college students in Henan province. 河南省大学生学习自主 性评价研究. Journal of Xinxiang University. 新乡学院学报 (26), 188-190 (2012). https://doi.org/10.3969/j.issn.16743334.2012.02.062

Wang, X.Y. et al.(2006). Investigation and analysis of the status quo of initiative in the study of college English. 大学英 语自主学习现状的调查与分析. Journal of Zhejiang Shuren University. 浙江树人大学学报. Vol.6, No.4, 64-67. Retrieved Jan. 2, 2018, from http://kns.cnki.net/KCMS/detail/detail.aspx?dbcode=CJFQ\&dbname=CJFD2006\& filename=ZJSR200604017\&uid=WEEvREcwSIJHSIdRa1FhcEEORVZxZnU1U2MVQZFMYOIRVFZOcGRhSTUwST0=\$9A4hF_ YAuvQ5obgVAgNKPCYcEjKensW4ggl8Fm4gTkoUKalD8j8gFw!!\&v=MDQyOTdXTTFGckNVUkxLZlp1WnRGeUhr VnJ6QIB5ZIImTECOSHRmTXEOOUVZNFI4ZVgXTHV4WVM3RGgXVDNxVHI=

YS Xiao, The abuses in the classroom teaching in the teachers' college and the countermeasure. 师专课堂教学中存在 的弊端和对策. Journal of HuaiHua Teachers College.怀化师专学报 (20), 92-95 (2001). https://doi.org/10.16074/j. Cnki.cn43-1394/z.2001.01.026

SW Xie, HM Zhang, On technology alienation and its solution. Journal of Leshan Normal University (6), 114-117 (2007) Retrieved Jan. 2, 2018, from http://kns.cnki.net/KCMS/detail/detail.aspx?dbcode=CJFQ\&dbname=CJFD2007\& filename $=L S S Z 200706031$ \&uid=WEEvREcwSIJHSIdRa1Fhb09jSnZpSU1GdVFVNS9sQ1FEWjLdmFSYUhGOD0=\$9A4hF_ YAuvQ5obgVAgNKPCYcEjKensW4gg|8Fm4gTkoUKalD8j8gFw!!\&v=MDU2MDIEaDFUM3FUcldNMUZyQ1VSTEtm WnVadEZDbm1VYnJLS1Q3WWRMRzRIdGJNcVk5R1pZUjhIWDFMdXhZUZc=

C Yen et al., Symptoms of problematic cellular phone use,functional impairment and its association with depression among adolescents in southern Taiwan. J. Adolesc. 32(4), 863-873 (2009) 
F Yin, R Wu, Study of flipped classroom teaching mode suitable for China's National Conditions. Social Computing (Part II). (9), 59-64 (2016)

F Yu, Study on the free option of courses in research-oriented universities in Canada and in China: A case study of Toronto University and Fudan University. 中国、加拿大研究型大学学生选课自由的比较——以多伦多大学与复 旦大学为例. Journal of Yunnan nationalities university(social sciences). 云南民族大学学报哲学社会科学版 (31), 155-160 (2014) Retrieved Jan. 2, 2018, from http://d.g.wanfangdata.com.cn/Periodical_ynmzxyxb-zxsh201401027.aspx Y Zhao, GA Cziko, Teacher adoption of technology: A perceptual control theory perspective. J Technol Teach Educ 9, 5-30 (2001)

HH Zhou, PT Dang, YH Jiang, Effects of mobile phones upon the development of college students and countermeasure to the problems. 手机对当代大学生发展的影响极其对策研究. China youth study. 中国青年研究 (6), 90-92 (2011). https://doi.org/10.19633/j.Cnki.11-2579/d.2011.06.021

GP Zhu, XJ Yu, Practice of application modes of MOOC resource for principles of electrical circuit. “电路原理"MOOC资 源的多种应用形式实践. Journal of EEE. 电气电子教育学报 39(3), 6-8 (2017). https://doi.org/10.3969/j.issn.10080686.2017.03.002

Zlemaan, Alaettinnsal, Neeelik, Evaluation of college students' level of addiction to cellular phone and investigation on the relationship between the addiction and the level of depression. Social and Behavioral Sciences 114, 831-839 (2014)

Submit your manuscript to a SpringerOpen ${ }^{\circ}$ journal and benefit from:

- Convenient online submission

- Rigorous peer review

- Open access: articles freely available online

High visibility within the field

- Retaining the copyright to your article

Submit your next manuscript at $\gg$ springeropen.com 